\title{
Periprosthetic joint infection due to Brucella infection: A report of a rare presentation and review of the literature
}

\author{
Mahmoud Jabalameli', Abolfazl Bagherifard ${ }^{2}$, Mohammad Taher Ghaderi ${ }^{3}$ Paniz Motaghi $^{4}$, \\ Hossein Akbari Aghdam ${ }^{3}$, \\ From ${ }^{1}$ Professor, ${ }^{2}$ Associate Professor, ${ }^{3}$ Fellowship, ${ }^{4}$ Research Manager, Bone and Joint Reconstruction Research Center, Shafa Yahyaeian Orthopedic \\ Hospital, Iran University of Medical Sciences, Tehran, Iran
}

\begin{abstract}
Periprosthetic infection (PJI) is a serious complication of total knee arthroplasty (TKA). PJI due to Brucellosis is a very rare entity. In this report, we described the case of knee joint loosening after TKA in a 63-year-old female who arrived with complaints of a restricted range of motion, stiffness, and pain. The diagnosis was made based on clinical, radiological, and laboratory findings. She was treated with antibiotics and two-stage revision surgery. We also reviewed all similar cases in the English literature from the epidemiologic, diagnostic, and treatment aspects and brought suggestions for evaluations before TKA in endemic areas. Authors emphasize that Brucellosis must be considered among differential diagnoses for patients with PJI, especially in endemic areas. Serologic evaluations and long-term blood and joint aspirated fluid culture must be performed when the patient has a history of recurrent febrile illness, joint swelling, and exposure to animals or the consumption of unpasteurized dairy products. Early suspicion of Brucellosis improves the outcome and prevents medical staff from being infected. A double therapy with doxycycline and rifampin for 6 months and performing two-stage revision surgery is the treatment of choice.
\end{abstract}

Key words: Brucella joint infection, Brucellosis, Knee prosthesis infection, Prosthesis infection, Total knee arthroplasty

$\mathrm{O}$ ver the past few years, the number of joint replacements for end-stage joint destruction has been gradually increased worldwide [1]. Total knee arthroplasty (TKA) is one of the most common joint replacement surgeries. Periprosthetic joint infection (PJI) is a deleterious complication after this surgery. PJI may result in the loosening that requires revision arthroplasty [2]. The occurrence of Brucella infection after TKA is a very rare condition. In our country, the incidence of Brucellosis has been recently increased, thus the PJI with Brucella must be more accurately considered among differential diagnoses [3]. Besides, the most common complication of Brucellosis is musculoskeletal involvement such as osteoarticular infection and arthritis [3]. In 2016, we diagnosed a case of PJI due to Brucellosis in a 68-yearold woman who was referred to an infectious disease specialist with complaints of pain and discharge from knee prosthesis 8 months after TKA. In this case, the diagnosis of PJI was made according to Parvizi et al. criterion [4]. Unfortunately, because we were clinically not suspected of the diagnosis of Brucellosis, safety laboratory precautions were not implemented while examining

\section{Access this article online}

Received - 20 February 2021

Initial Review - 11 March 2021

Accepted - 03 May 2021

DOI: $10.32677 /$ IJCR.2021.v07.i04.011 the specimen, the physician, and laboratory technician became infected [5]. Although the occurrence of PJI due to Brucellosis is a very rare entity [6], early diagnoses of this rare presentation lead to a better outcome and avoid unwitting infection of laboratory staff.

Here, we report the second case of PJI due to Brucellosis who was diagnosed at our institute. Furthermore, a review of all cases of Brucella species PJI in the English literature from the epidemiologic, diagnostic, and treatment aspects was done.

\section{CASE REPORT}

A 63-year-old female housewife underwent a total knee arthroplasty for the treatment of right knee degenerative osteoarthritis. Two years after the surgery, she was referred to an infectious specialist with complaints of uncontrolled fever and intermittent knee pain on the operated side.

Laboratory evaluations showed normal cell blood count (CBC) with slight elevation in the erythrocyte sedimentation rate (ESR) $(69 \mathrm{~mm} / \mathrm{h})$ and C-reactive protein (CRP) (2+). Further evaluations did not reveal any source of infection; however, she received triple antibiotic therapy comprising vancomycin, meropenem, and

Correspondence to: Paniz Motaghi, Shafa Yahyaeian Research Committee, Mojahedin Eslam St, District 12, Tehran, Iran. E-mail: paniz.motaqi@gmail.com

(C) 2021 Creative Commons Attribution-NonCommercial 4.0 International License (CC BY-NC-ND 4.0). 
rifampin.

At first, the symptoms were relieved; but 10 months later, she arrived back with a complaint of intermittent pain, fever $\left(39^{\circ} \mathrm{C}\right)$, chill, and a swollen knee. On examination, the vital signs were stable with a blood pressure of $120 / 73$, heart rate of $79 / \mathrm{min}$, and respiratory rate of $21 / \mathrm{min}$. This time, she was treated by teicoplanin and rifampin under the supervision of an infectious disease specialist.

After 14 months, the patient again complained of fever, knee pain, and severe joint swelling, so she was admitted for the third time after her TKA surgery and this time rifampin, clindamycin, and tavanex were administered. After discharge, she was referred from another center to our department of orthopedic surgery. On examination, erythema and swelling around her knee joint and restricted range of motion (ROM) were observed.

ESR and CRP were elevated $(53 \mathrm{~mm} / \mathrm{hr}$ and CRP $21 \mathrm{mg} / \mathrm{L})$. A whole-body bone scan was obtained and manifested an increased radiotracer uptake in her right knee. Radiographic findings were suggestive of the loosening of the prosthesis (Fig. 1). Knee aspiration was performed under sterile conditions and the specimen was sent for analysis and culture. Leukocytosis was not seen and no bacteria were grown on routine media after $48 \mathrm{~h}$.

According to the clinical and radiologic findings and high ESR and CRP, a two-stage revision arthroplasty was scheduled for her. We entirely debrided synovial tissue and other surrounding tissues in the joint and synovial fluid, synovial tissue, and bone was sent for microbiological evaluations, and long-term incubation was requested to rule out Brucella infection. After the sterilization of the femoral component, it was placed with the cement on the femoral side and a new polyethylene spacer was inserted in the tibial side with the cement (Fig. 2a). The wound was closed using routine techniques. This time we warned laboratory technicians about the possibility of Brucellosis. As expected, the long-term culture was positive for Brucella. The serologic test for Brucellosis on the specimen was also positive.

Double anti-Brucella therapy using a combination of oral rifampin and oral doxycycline was administered for 6 months. As soon as the antibiotic therapy was completed and we achieved

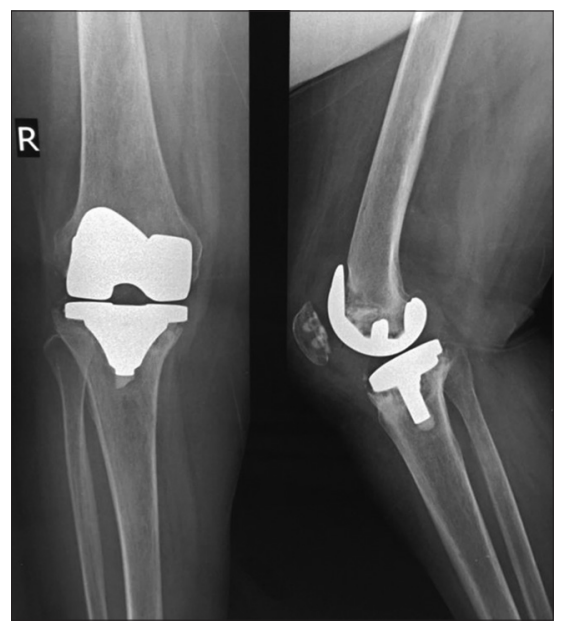

Figure 1: Anteroposterior and lateral radiographic view of the involved knee - evidence of loosening of the prosthesis a negative serologic test result, the second stage of total knee revision was performed. During the operation, temporary components were extracted and replaced by permanent ones (Fig. 2b). All cultures of intraoperative specimens were negative after prolonged incubation. She had and an uneventful postoperative course without any sign of recurrence. At the end of the two-year follow-up period, she was asymptomatic and had a good knee joint function.

\section{DISCUSSION}

Brucellosis is a zoonotic infection caused by the bacterial genus Brucella. The main risk factors of Brucellosis the consumption of unpasteurized dairy products and less commonly contact with raw meat or working in farmlands. Infection after total knee replacement is a serious complication and is associated with a high incidence of morbidity [6]. PJI due to Brucella spp. is an extremely rare condition that can result in septic loosening and require revision treatment.

Since the first case of knee PSI due to Brucella infection, 25 other patients (including the current case) have been reported in the English literature, with a presentation of knee pain and swelling years after TKA surgery, that did not respond to wide spectrum antibiotic therapy and ended with either positive tissue culture or serologic test suggesting Brucella infection. In the current case report, we included all cases published in PubMed and Scopus and tried to evaluate their similar features. Three main categories of data were extracted from articles: (a) Risk factors and geographical distribution, (b) diagnostic criteria, and (c) treatment strategy and outcome. All information is summarized in Tables 1-3 [6-26].

This infectious disease is globally distributed, two of the most endemic regions are the Mediterranean basin and Greece [27]. A similar distribution is seen among reported cases of PJI due to Brucellosis; 17 cases of all 26 patients were found in middle east countries, with Turkey and Iran accounting for $23 \%$ and $15 \%$ of them, respectively.

In 2016, we diagnosed a case of PJI due to Brucellosis in a 68-year-old woman who was referred to an infectious disease specialist with complaints of pain and discharge from knee prosthesis 8 months after TKA. Despite the negative culture of aspirated fluid,

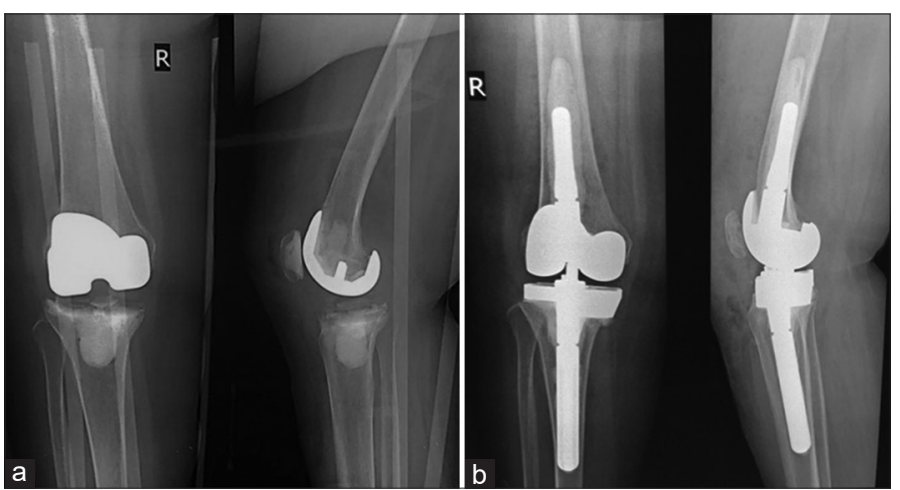

Figure 2: Anteroposterior and lateral view of the involved knee. After the (a) first step and (b) second step of revision surgery 
Table 1: Risk factors and geographical distribution of the knee PJI cases due to Brucellosis

\begin{tabular}{|c|c|c|c|c|}
\hline Year & $1^{\text {st }}$ author [Reference number] & Reference number & Country exposure (endemic) & Risk factor \\
\hline 1991 & Agarwal [6] & 7 & Saudi Arabia & $\mathrm{Na}$ \\
\hline 1997 & Iglesias [7] & 8 & Spain & $\mathrm{Na}$ \\
\hline 1997 & Orti [8] & 9 & Spain & Contact with goat \\
\hline 1997 & Malizos [9] & 10 & Greece & Shepherd \\
\hline 2003 & Weil [10] & 11 & Israel & Unpasteurized dairy products \\
\hline 2003 & Weil [10] & 11 & Israel & Unpasteurized dairy products \\
\hline 2006 & Marchese [11] & 12 & Italy & Unpasteurized dairy products \\
\hline 2007 & Marbach [12] & 13 & Italy & Unpasteurized dairy products \\
\hline 2008 & Tassinari [13] & 14 & Italy & $\mathrm{Na}$ \\
\hline 2008 & Atay [14] & 15 & Turkey & Unpasteurized dairy products \\
\hline 2009 & Dauty [15] & 16 & Portugal & Unpasteurized dairy products \\
\hline 2010 & Erdogan $[16]$ & 17 & Turkey & Unpasteurized dairy products \\
\hline 2011 & Wunschel [17] & 18 & Turkey & Unpasteurized dairy products \\
\hline 2012 & Oner [5] & 6 & Turkey & $\mathrm{Na}$ \\
\hline 2014 & Karaaslan [18] & 19 & Turkey & $\mathrm{Na}$ \\
\hline 2016 & Jabalameli [4] & 5 & Iran & $\mathrm{Na}$ \\
\hline 2016 & Lewis [19] & 20 & Thailand & Contact with goats \\
\hline 2016 & Sazegar [2] & 2 & Iran & $\mathrm{Na}$ \\
\hline 2016 & Klassove [20] & 21 & Israel & Contact with raw meat \\
\hline 2017 & Flury [21] & 22 & Turkey & Unpasteurized dairy products \\
\hline 2017 & Mortazavi [1] & 1 & Iran & Non-pasteurized dairy products \\
\hline 2017 & Turvey [22] & 23 & Canada & Consumed raw meat \\
\hline 2018 & Maalouf [23] & 24 & Lebanon & Unpasteurized dairy products \\
\hline 2019 & Balkhair [24] & 25 & Oman & Unpasteurized dairy products \\
\hline 2019 & Hamdi [25] & 26 & Saudi Arabia & Unpasteurized dairy products \\
\hline This case & & & Iran & Unpasteurized dairy products \\
\hline
\end{tabular}

she was treated with antibiotics, but the discharge did not stop. One year later, she was referred to our institute with complaints of severe stiffness, pain, and discharge from the fistula. Pre-operative evaluations, including knee aspiration fluid examination and blood culture, were negative after $48 \mathrm{~h}$, and ESR and CRP were within normal ranges. At last, because no reason for her painful joint was found and joint loosening was observed in radiography, diagnosis of PJI was made according to Parvizi et al. [4]. definition and diagnostic criteria, and a revision arthroplasty was performed. Synovial fluid and prosthesis culture were requested.

Our center is a revision referral center; we routinely keep all synovial fluid and joint cultures for a long time. After long-term incubation of the intraoperative specimens, cultures returned positive for Brucella infection and she received combined antibiotic therapy through rifampin and doxycycline for 6 months. Unfortunately, because we were clinically not suspected of the diagnosis of Brucellosis, safety laboratory precautions were not implemented while examining the specimen, the physician, and laboratory technician became infected [5].

Clinical presentations of Brucellosis are non-specific, thus there is a high chance of misdiagnosing these patients [26]. Symptoms include chills, fever, malaise, sweating, hepatomegaly, and splenomegaly. It may also involve the musculoskeletal system and leads to joint swelling and infection [3].
To confirm the diagnosis of Brucellosis, it is necessary to isolate the organism from blood culture and perform serologic tests [28]. Septic and reactive forms are two pathogenic mechanisms of Brucella that affect joints. The septic form seems more probable as Brucella spreads through the bloodstream, as in other bacterial arthritis [29]. Agarwal described the first case with a PJI caused by Brucella in 1991 [7]. Weil in 2003 presented a report of three patients, one of them was infected, TKA was done, and the diagnosis was made by tissue culture during surgical debridement. After 6 weeks of combined antibiotic therapy against Brucella, second-stage surgical revision was done, and additional combined antibiotic treatment continued for 6 weeks [11]. Among all 26 reviewed patients of Brucella-related PJI, 24 patients (92\%) had tenderness, 11 (42\%) had swollen knees, and 5 (19\%) had limited ROM. PJI in 14 patients (54\%) was also associated with systemic presentations, including intermittent fever, chills, malaise, fatigue, and night sweat. The mean interval between the TKA surgery and symptoms was $64.7 \pm 5.1$ months (ranging from 2.5 to 168 months). The amount of ESR was missing in 13 patients; however, it was elevated in 11 cases out of the rest of them. In twenty patients, a serologic test was performed and revealed positive results except for one patient, whose test was negative, with a titer of $<1: 40$. The culture of aspirated fluid from the infected joint was positive for Brucella in 18 patients and 
Table 2: Diagnostic features of the knee PJI cases due to Brucellosis

\begin{tabular}{|c|c|c|c|c|c|c|c|c|c|}
\hline Year & $\begin{array}{l}1^{\text {st }} \text { author } \\
\text { [Reference } \\
\text { number] }\end{array}$ & $\begin{array}{l}\text { Local } \\
\text { presentation }\end{array}$ & $\begin{array}{l}\text { Systemic } \\
\text { presentation }\end{array}$ & $\begin{array}{l}\text { Interval TKA } \\
\text { to symptom }\end{array}$ & Serology & Aspiration & $\begin{array}{l}\text { Tissue } \\
\text { culture }\end{array}$ & ESR & Radiologic findings \\
\hline 1991 & Agarwal [7] & $\begin{array}{l}\text { Superficial } \\
\text { infection, Abscess }\end{array}$ & No & $2.5 \mathrm{~m}$ & $+(2560)$ & + & + & $\mathrm{Na}$ & No loosening \\
\hline 1997 & Iglesias [8] & $\begin{array}{l}\text { Swelling, Knee } \\
\text { pain }\end{array}$ & Yes & $48 \mathrm{~m}$ & + & + & $\mathrm{Na}$ & $\mathrm{Na}$ & No loosening \\
\hline 1997 & Orti [9] & Knee pain & No & $14 \mathrm{~m}$ & + & + & + & 57 & No loosening \\
\hline 1997 & Malizos [10] & $\begin{array}{l}\text { Synovitis, knee } \\
\text { pain }\end{array}$ & Yes & $5 \mathrm{~m}$ & + & + & + & $\mathrm{Na}$ & No loosening \\
\hline 2003 & Weil [11] & $\begin{array}{l}\text { Swollen, painful, } \\
\text { warm knee }\end{array}$ & No & $36 \mathrm{~m}$ & $+(1600)$ & + & $\begin{array}{l}-(\mathrm{A} . \\
\text { baumanii) }\end{array}$ & $\mathrm{Na}$ & $\begin{array}{l}\text { Loosening of both } \\
\text { femoral } \\
\text { And tibial components }\end{array}$ \\
\hline 2003 & Weil [11] & Knee pain & Yes (fever) & $168 \mathrm{~m}$ & $+(1600)$ & + & + & 76 & $\begin{array}{l}\text { Bone scanning } \\
\text { revealed increased } \\
\text { uptake in the lumbar } \\
\text { spine, the right } \\
\text { sacroiliac joint, and the } \\
\text { left knee. Plain knee } \\
\text { radiography } 7 \text { revealed } \\
\text { mild loosening of the } \\
\text { femoral component. }\end{array}$ \\
\hline 2006 & Marchese [12] & $\begin{array}{l}\text { Keen pain, } \\
\text { swelling }\end{array}$ & No & $108 \mathrm{~m}$ & $\mathrm{Na}$ & + & + & $\mathrm{Na}$ & Loosening \\
\hline 2007 & Marbach [13] & Knee pain & No & $48 \mathrm{w}$ & $\mathrm{Na}$ & - & + & $\mathrm{Na}$ & Loosening \\
\hline 2008 & Tassinari [14] & Knee pain & No & $24 \mathrm{~m}$ & $+(800)$ & + & + & 81 & $\begin{array}{l}\text { Small area of } \\
\text { resorption on tibial } \\
\text { component } \\
\text { No loosening }\end{array}$ \\
\hline 2008 & Atay [15] & Knee pain & No & $48 \mathrm{~m}$ & + & $\mathrm{Na}$ & + & $\mathrm{Na}$ & No loosening \\
\hline 2009 & Dauty [16] & Discharge, & Yes & $\mathrm{Na}$ & $\mathrm{Na}$ & - & + & 60 & $\begin{array}{l}\text { Loosening of tibial } \\
\text { plateau }\end{array}$ \\
\hline 2010 & Erdogan [17] & Knee pain, & $\begin{array}{l}\text { Yes (chills, } \\
\text { Fever) }\end{array}$ & $24 \mathrm{~m}$ & + & + & + & 43 & No loosening \\
\hline 2011 & Wunschel [18] & Knee pain & No & $60 \mathrm{~m}$ & + & + & $\mathrm{Na}$ & $\mathrm{Na}$ & Loosening \\
\hline 2012 & Oner [6] & Knee pain & Yes & $96 \mathrm{~m}$ & + & + & $\mathrm{Na}$ & $\mathrm{Na}$ & Loosening \\
\hline 2014 & Karaaslan [19] & $\begin{array}{l}\text { Swelling, knee } \\
\text { pain }\end{array}$ & Yes (Fever) & $24 \mathrm{~m}$ & + & + & $\mathrm{Na}$ & $\mathrm{Na}$ & Loosening \\
\hline 2016 & Jabalameli [5] & $\begin{array}{l}\text { Knee pain, and } \\
\text { stiffness, discharge }\end{array}$ & No & $12 \mathrm{~m}$ & $\mathrm{Na}$ & - & + & 20 & Loosening \\
\hline 2016 & Lewis [20] & $\begin{array}{l}\text { Swelling, knee } \\
\text { pain, fever }\end{array}$ & Yes & $60 \mathrm{~m}$ & + & + & $\mathrm{Na}$ & $\mathrm{Na}$ & No loosening \\
\hline 2016 & Sazegar [2] & $\begin{array}{l}\text { Knee pain, } \\
\text { limited ROM, } \\
\text { swelling, warm }\end{array}$ & No & $60 \mathrm{~m}$ & + & $\mathrm{Na}$ & $\mathrm{Na}$ & 105 & $\begin{array}{l}\text { Components } \\
\text { loosening }\end{array}$ \\
\hline 2016 & Klassove [21] & Knee pain & No & $\begin{array}{l}144 \mathrm{~m} \text { before } \\
\text { presentation in } \\
\text { the left knee } \\
\text { and } 48 \mathrm{~m} \text { before } \\
\text { presentation in } \\
\text { the right knee. }\end{array}$ & $\begin{array}{l}\operatorname{IgG} \\
1: 640 \\
\operatorname{IgM} \\
1: 1920 .\end{array}$ & & + & 80 & $\begin{array}{l}\text { Increased uptake in } \\
\text { the left knee around } \\
\text { the implant }\end{array}$ \\
\hline 2017 & Flury [22] & Knee pain & No & $144 \mathrm{~m}$ & $+(240)$ & + & + & $\mathrm{Na}$ & $\begin{array}{l}\text { Loosening of the } \\
\text { prosthesis } \\
\text { With migration of the } \\
\text { tibial component }\end{array}$ \\
\hline
\end{tabular}


Table 2:(Continued)

\begin{tabular}{|c|c|c|c|c|c|c|c|c|c|}
\hline Year & $\begin{array}{l}\mathbf{1}^{\text {st }} \text { author } \\
\text { [Reference } \\
\text { number] }\end{array}$ & $\begin{array}{l}\text { Local } \\
\text { presentation }\end{array}$ & $\begin{array}{l}\text { Systemic } \\
\text { presentation }\end{array}$ & $\begin{array}{l}\text { Interval TKA } \\
\text { to symptom }\end{array}$ & Serology & Aspiration & $\begin{array}{l}\text { Tissue } \\
\text { culture }\end{array}$ & ESR & Radiologic findings \\
\hline 2017 & Mortazavi [1] & $\begin{array}{l}\text { Pain, swelling, } \\
\text { and limitations in } \\
\text { the ROM }\end{array}$ & $\begin{array}{l}\text { Yes (fatigue, } \\
\text { low-grade } \\
\text { fever and } \\
\text { night } \\
\text { sweats.) }\end{array}$ & $48 \mathrm{~m}$ & $+(1280)$ & + & + & 51 & $\begin{array}{l}\text { Effusion and soft } \\
\text { tissue swelling but the } \\
\text { prosthesis was stable } \\
\text { and had no evidence } \\
\text { of loosening after } 18 \mathrm{n} \\
\text { months of conservative } \\
\text { treatment, loosening } \\
\text { occurred }\end{array}$ \\
\hline 2017 & Turvey [23] & $\begin{array}{l}\text { Knee pain, unable } \\
\text { to bear weight, } \\
\text { effusion, limited } \\
\text { ROM }\end{array}$ & $\begin{array}{l}\text { Yes } \\
\text { (intermittent } \\
\text { fevers) }\end{array}$ & $132 \mathrm{~m}$ & $-(1 / 40)$ & $\mathrm{Na}$ & + & 67 & $\begin{array}{l}\text { Loosening and } \\
\text { subsidence of the } \\
\text { tibial component } \\
\text { With lucency seen in } \\
\text { the proximal tibia. }\end{array}$ \\
\hline 2018 & Maalouf [24] & $\begin{array}{l}\text { Tenderness, } \\
\text { swelling, and } \\
\text { redness, unable to } \\
\text { bear weight. }\end{array}$ & $\begin{array}{l}\text { Yes (night } \\
\text { sweats and } \\
\text { chills) }\end{array}$ & $24 \mathrm{~m}$ & $+(5120)$. & $\mathrm{Na}$ & + & $\mathrm{Na}$ & $\begin{array}{l}\text { Loosening of the tibial } \\
\text { prosthesis and evidence } \\
\text { of osteomyelitis }\end{array}$ \\
\hline 2019 & Balkhair [25] & $\begin{array}{l}\text { Knee pain, } \\
\text { swelling, } \\
\text { moderate effusion }\end{array}$ & $\begin{array}{l}\text { Yes (indolent } \\
\text { fever, night } \\
\text { sweats, and } \\
\text { malaise) }\end{array}$ & $120 \mathrm{~m}$ & $\mathrm{Na}$ & + & + & 109 & $\begin{array}{l}\text { Bilateral increased } \\
\text { radiotracer uptake } \\
\text { around both knee joint } \\
\text { prostheses compatible } \\
\text { with periprosthetic } \\
\text { joint infection }\end{array}$ \\
\hline 2019 & Hamdi [26] & $\begin{array}{l}\text { Knee pain, } \\
\text { swelling, and } \\
\text { limited ROM }\end{array}$ & $\begin{array}{l}\text { Yes } \\
\text { (intermittent } \\
\text { fever and } \\
\text { weight loss) }\end{array}$ & $144 \mathrm{~m}$ & $\mathrm{Na}$ & - & + & 112 & Component loosening \\
\hline \multicolumn{2}{|c|}{ This case } & $\begin{array}{l}\text { Tenderness, } \\
\text { erythema, and } \\
\text { swelling around } \\
\text { her knee joint } \\
\text { ROM was } \\
\text { restricted }\end{array}$ & $\begin{array}{l}\text { Intermittent } \\
\text { fever, night } \\
\text { sweat }\end{array}$ & $24 \mathrm{~m}$ & + & + & + & 106 & $\begin{array}{l}\text { Increased radiotracer } \\
\text { around involved knee, } \\
\text { prosthesis loosening }\end{array}$ \\
\hline
\end{tabular}

TKA: Total knee arthroplasty, ESR: Erythrocyte sedimentation rate, ROM: Range of motion

negative in 4 patients. During surgeries, the specimens were taken for 20 patients; Brucella was isolated in media after prolonged incubation. According to our review of the literature, cultures of intraoperative tissue samples provide the best yield.

In radiography, 16 joints showed prosthesis loosening. An increased in radiotracers was occurred in four patients. The pathogenesis of septic loosening of the prosthetic joint is unknown. There are two mechanisms suggested in the English literature: Reactive and septic forms. However, the latter seems more common in reported cases [29].

For Brucellosis treatment, combination antimicrobial therapy is usually favored over monotherapy because high relapse rates have been reported with monotherapy. In the absence of prosthesis, oral doxycycline is prescribed for six weeks either with streptomycin (for 2-3 weeks) or rifampin (for 6 weeks). Despite the remaining controversy surrounding the best treatment approach for Brucella spp. PJIs, the current consensus is that dual or triple antibiotic therapy may be superior, particularly if the prosthesis is retained. However, there is no agreement on the duration of treatment [22-25]. While Brucella PJI without radiological loosening is thought to be completely treated through conservative approach and solely with double or triple therapy, surgeons emphasize that performing two-step revision surgery for removal and replacing prosthesis component is mandatory when prosthesis loosening occurs $[23,25]$. We also agree that twostage revision is required for the treatment of patients with prosthetic loosening. Despite the good outcome achieved in eight patients who did not have prosthesis loosening by sole antibiotic therapy, one-stage revision surgery, or arthroscopic debridement was done (Tables 2 and 3). We claim that all cases of PJI due to Brucellosis would involve bone tissue; hence, all patients should undergo two-stage revision surgery regardless of the joint loosening.

According to our review of the literature, the best medication therapy for cases with prosthesis involvement to be given between two stages of surgery would be a combination of doxycycline and rifampin for at least 6 weeks combined with an aminoglycoside (usually streptomycin). However, we believe dual therapy by rifampin and doxycycline for 6 months can achieve a great outcome without recurrence. Other researchers have applied a wide range of protocols that are summarized in Table 3 that consist of doxycycline and rifampin for at least 6 weeks and relapse of infectious only occurred in few cases that required continuing the medical treatment for a longer period. Overall, relapse is uncommon, even with 
Table 3: Treatment strategy for knee PJI cases due to Brucellosis

\begin{tabular}{|c|c|c|c|c|c|c|}
\hline Year & $\begin{array}{l}1^{\text {st }} \text { author } \\
\text { [reference } \\
\text { number] }\end{array}$ & Medical (AB) & Surgical & $\begin{array}{l}\text { Implant free } \\
\text { interval }\end{array}$ & Outcome & $\begin{array}{l}\text { Relapse (in } \\
2 \text { years) }\end{array}$ \\
\hline 1991 & Agarwal [7] & Dox/Rif 76w & None & 0 & Good & - \\
\hline 1997 & Iglesias [8] & Dox/Rif $6.5 w$; then Strep (3w)/Dox $12 \mathrm{w}$ & None & 0 & Good & \\
\hline 1997 & Orti [9] & Strep/Dox/Rif 6w & None & 0 & Good & \\
\hline 1997 & Malizos [10] & Strep (3w)/Dox 20w, then Bact $8 w$ & None & 0 & Good & - \\
\hline 2003 & Weil [11] & $\operatorname{Dox}+\operatorname{Rif}(6 w)$ & 2 stage revision & $6 \mathrm{w}$ & Good & - \\
\hline 2003 & Weil [11] & $\operatorname{Dox}+\operatorname{Rif}(6 w)$ & 2 stage revision & $6 \mathrm{w}$ & Good & - \\
\hline 2006 & Marchese [12] & Strep/Dox 4w, then Dox/Rif/Levo $32 \mathrm{w}$ & Implant removal & - & Good & \\
\hline 2007 & Marbach [13] & Dox/Rif $12 \mathrm{w}$ & 2 stage revision & $12 \mathrm{w}$ & Good & \\
\hline 2008 & Tassinari [14] & Dox/Rif $8 w$ & None & 0 & Good & - \\
\hline 2008 & Atay [15] & Dox/Rif 6wk & $\begin{array}{l}\text { Debridement, antibiotics, irrigation } \\
\text { and retention. (arthroscopy) }\end{array}$ & 0 & Good & \\
\hline 2009 & Dauty [16] & Dox/Rif $12 \mathrm{w}$ & 2 stage revision & 6 & Good & - \\
\hline 2010 & Erdogan [17] & Dox/Rif $16 \mathrm{w}$ & None & 0 & Good & \\
\hline 2011 & Wunschel [18] & Dox/Rif $24 \mathrm{w}$ & 1 stage revision & 0 & Good & \\
\hline 2012 & Oner [6] & Dox/Rif $16 \mathrm{w}$ & 2 stage revision & $20 w$ & Good & \\
\hline 2014 & Karaaslan [19] & Dox/Rif $12 \mathrm{w}$ & 2 stage revision & $12 \mathrm{w}$ & Good & \\
\hline 2016 & Jabalameli [5] & Dox/Rif $24 w$ & 2 stage revision & $24 \mathrm{w}$ & Good & \\
\hline 2016 & Lewis [20] & Gen $(2 \mathrm{w}) /$ Dox/Rif $24 \mathrm{w}$ & None & 0 & Good & \\
\hline 2016 & Sazegar [2] & Dox/Rif 8 w & 2 stage revision & $8 w$ & Good & \\
\hline 2016 & Klassove [21] & Gen $(3 \mathrm{w}) /$ Dox and Rif $12 \mathrm{w}$ & 2 stage revision & $8 w$ & Good & + \\
\hline 2017 & Flury [22] & Dox/Rif/Pen 24 w & 2 stage revision & $2.5 \mathrm{w}$ & Good & \\
\hline 2017 & Mortazavi [1] & Dox/Rif/YMP-SMX 24 w & 2 stage revision & $16 \mathrm{w}$ & Good & \\
\hline 2017 & Turvey [23] & Gen $(2 w) / D o x$ and Rif (12w) & 2 stage revision & $\mathrm{Na}$ & Good & - \\
\hline 2018 & Maalouf [24] & Gen/Rif/Dox 16 w & 2 stage revision & na & Good & - \\
\hline 2019 & Balkhair [25] & Gen $(1 w) /$ Dox and Rif $24 w$ & 1 stage revision & 0 & Good & - \\
\hline 2019 & Hamdi [26] & $\operatorname{Rif}(24 w)+\operatorname{Rif} / \operatorname{Strep}(48 w)$ & 2 stage revision & $8 w$ & Good & - \\
\hline \multicolumn{2}{|c|}{ This case } & Rif/Dox 24 w & 2 stage revision & $24 \mathrm{w}$ & Good & - \\
\hline
\end{tabular}

W: Week, Rif: Rifampin, Dox: Doxycycline, Strep: Streptomycin, Pen: Penicillin, Gen: Gentamycin, Levo: Levofloxacin, Bact: Bactomycin

shorter treatment durations, and is typically caused by failure to complete treatment or lack of source control rather than antibiotic resistance [23]. Fluri in 2016 reported a case of TKA infected by Brucella. Their treatment protocol consists of combined antibiotic therapy 1 week before the second stage of revision surgery and 3 months after that was applied for their patients. They also reviewed 30 cases of PJI caused by Brucellosis that 18 of them were infected TKA. In these cases, if the infection by Brucellosis was suspected, the serological tests for Brucellosis were evaluated, and the cultures incubated for a longer period to detect the Brucella spp. [22].

At last, PJI due to Brucella, although rare, can occur especially in endemic areas. In these areas, serologic tests for Brucella infection should be included in pre-operative laboratory evaluations, and also physicians should consider Brucellosis and perform serologic evaluations in patients who arrive with a painful or swollen prosthetic knee joint. We necessitate the importance of considering the history of using dairy products, and the occurrence of joint loosening in cases of PJI, as two key criteria suggesting Brucella joint infection. Since the laboratory cultures of Brucella spp. are often unsuccessful due to their slow rate of growth and require special media with high $\mathrm{CO}_{2}$ tension, a negative culture cannot rule out this diagnosis. Thus, the routine test of Wright, Coombs Wright, and 2-Mercaptoethanol (2ME) tests are recommended in all prosthetic joints that are suspected of infection [29-31].

As Brucellosis is the most common laboratory-acquired infection that can easily transmit, while examining the infected specimen through aerosolization [32,33], when suspecting Brucella joint infection, safety laboratory precautions must be implemented, especially in regions of high endemicity. For all exposed individuals, prophylactic treatment through doxycycline and rifampin for three weeks and follow-up serologic testing is recommended. In patients with an epidemiological risk, Brucellosis should be included in the list of potential causes of an infected prosthetic joint. Furthermore, considering a diagnosis of Brucella-related PJI would prevent medical staff from being infected while working with body fluids either during surgeries or performing laboratory tests.

\section{CONCLUSION}

Brucella-related PJI is a late complication of knee joint arthroplasty, with a mean onset of 64 months after the procedure. We must include this entity in the differential diagnosis of infected 
prosthetic joints who arrive with worsening pain and restricted range of motion who are resistant to primary antibiotic therapy. For similar clinical manifestations, we recommend physicians perform serologic evaluations and long-term blood and joint aspirated fluid culture, especially when the patient has a history of recurrent febrile illness, joint swelling, and either occupational exposure to animals or the consumption of unpasteurized milk or cheese. We suggest that practitioners should apply a double therapy with doxycycline and rifampin for 6 months to avoid relapse and perform two-stage revision surgery in the occurrence of prosthesis loosening.

\section{REFERENCES}

1. Mortazavi SM, Sobhan MR, Mazoochy H. Brucella arthritis following total knee arthroplasty in a patient with hemophilia: A case report. Arch Bone Joint Surg 2017;5:342-6.

2. Sazegari MA, Bahramian F, Mirzaee F, Zafarani Z, Aslani H. Loosening of total knee arthroplasty after brucellosis infection: A case report. Arch Bone Joint Surg 2017;5:70-2.

3. Hashemi SH, Keramat F, Ranjbar M, Mamani M, Farzam A, Jamal-Omidi S. Osteoarticular complications of brucellosis in Hamedan, an endemic area in the west of Iran. Int J Infect Dis 2007;11:496-500.

4. Aggarwal VK, Rasouli MR, Parvizi J. Periprosthetic joint infection: Current concept. Indian J Orthop 2013;47:10-7.

5. Jabalameli M, Bagherifard A, Hadi H, Qomashi I. Infected total knee arthroplasty by Brucella melitensis: A rare case report. J Res Orthop Sci 2016;3:3.

6. Öner M, Güney A, Halıcı M, Kafadar İ. Septic loosening due to Brucella melitensis after bilateral knee prosthesis and two-stage total knee prosthesis revision. Erciyes Med J 2012;34:97-9.

7. Agarwal S, Kadhi SK, Rooney RJ. Brucellosis complicating bilateral total knee arthroplasty. Clin Orthop Relat Res 1991;267:179-81.

8. Iglesias G, Arboleya L, Arranz J. Brucellar arthritis in a knee with prosthesis. Rev Esp Reumatol 1997;24:32-3.

9. Orti A, Roig P, Alcalá R, Navarro V, Salavert M, Martin C, et al. Brucellar prosthetic arthritis in a total knee replacement. Eur J Clin Microbiol Infect Dis 1997; 16:843-5.

10. Malizos KN, Makris CA, Soucacos PN. Total knee arthroplasties infected by Brucella melitensis: A case report. Am J Orthop (Belle Mead NJ) 1997;26:283-5.

11. Weil Y, Mattan Y, Liebergall M, Rahav G. Brucella prosthetic joint infection: A report of 3 cases and a review of the literature. Clin Infect Dis 2003;36:e81-6.

12. Marchese M, Bianchi G, Cavenago C. Total knee prosthesis infection by Brucella melitensis: Case report and review of the literature. J Orthop Traumatol 2006;7:150-3.

13. Marbach F, Saiah L, Fischer JF, Huismans J, Cometta A. Infection of a total knee prosthesis with Brucella spp. Rev Med Suisse 2007;3:1007-9.

14. Tassinari E, Di Motta D, Giardina F, Traina F, De Fine M, Toni A. Brucella infection in total knee arthroplasty. Case report and revision of the literature. Chir Organi Mov 2008;92:55-9.

15. Atay T, Baydar ML, Heybeli N. Brucellar prosthetic infection after total knee arthroplasty: A case with retained prosthesis by arthroscopic and medical treatment. Trakya Univ Tip Fak Derg 2008;25:252-5.
16. Dauty M, Dubois C, Coisy M. Bilateral knee arthroplasty infection due to Brucella melitensis: A rare pathology? Joint Bone Spine 2009;76:215-6.

17. Erdogan H, Cakmak G, Erdogan A, Arslan H. Brucella melitensis infection in total knee arthroplasty: A case report. Knee Surg Sports Traumatol Arthrosc 2010;18:908-10.

18. Wunschel M, Olszowski AM, Weissgerber P, Wulker N, Kluba T. Chronic brucellosis: A rare cause of septic loosening of arthroplasties with high risk of laboratory-acquired infections. Z Orthop Unfall 2011;149:33-6.

19. Karaaslan F, Mermerkaya M, Karaoğlu S, Ayvaz M. Total knee arthroplasty infected by Brucella melitensis septic loosening and long-term results of two-stage revision knee arthroplasty. J Surg 2014;10:241-2.

20. Lewis JM, Folb J, Kalra S, Squire SB, Taegtmeyer M, Beeching NJ. Brucella melitensis prosthetic joint infection in a traveller returning to the UK from Thailand: Case report and review of the literature. Travel Med Infect Dis 2016;14:444-50.

21. Klassov Y, Klassov TM, Peretz O, Benkovich V. Review of periprosthetic infection of Brucellosis with presentation of a case report. Am J Infect Dis 2016;12:65-72.

22. Flury D, Behrend H, Sendi P, von Kietzell M, Strahm C. Brucella melitensis prosthetic joint infection. J Bone Joint Infect 2017;2:136-42.

23. Turvey S, Hui C, Tyrrell G, Singh AE. Brucella suis as a cause of late prosthetic joint infection: A case report and review of the literature. Official J Assoc Med Microbiol Infect Dis Canada 2017;2:69-74.

24. Maalouf p, Abdallah A, Barakat A, Matta M. Periprosthetic knee infection with Brucella SPECIES: A case report. J Med Liban 2018;66:46-8.

25. Balkhair A, Maskari SA, Ibrahim S, Busaidi IA, Amin MA, Taher HB. Brucella periprosthetic joint infection involving bilateral knees with negative synovial fluid alpha-defensin. Case Rep Infect Dis 2019;2019:9423946.

26. Hamdi A, Ghalimah B. Brucellosis of knee prosthesis: A case report and review of the literature. MOJ Orthop Rheumatol 2019;11:169-72.

27. Andriopoulos P, Tsironi M, Deftereos S, Aessopos A, Assimakopoulos G. Acute brucellosis: Presentation, diagnosis, and treatment of 144 cases. Int J Infect Dis 2007;11:52-7.

28. Bosilkovski M, Siskova D, Spasovska K, Vidinic I, Dimzova M. The influence of illness duration before diagnosis on clinical characteristics and outcome in human brucellosis. Trop Doct 2019;49:177-81.

29. Tena D, Romanillos O, Rodríguez-Zapata M, Torre BD, Pérez-Pomata MT, Viana R, et al. Prosthetic hip infection due to Brucella melitensis: Case report and literature review. Diagn Microbiol Infect Dis 2007;58:481-5.

30. Ranjbar M. Treatment of brucellosis. In: Updates on Brucellosis. London: IntechOpen Limited; 2015. p. 171.

31. Shenoy B, Jaiswal A, Vinod A. Lab diagnosis of brucellosis. Pediatr Infect Dis 2016;8:40-4.

32. Fiori PL, Mastrandrea S, Rappelli P, Cappuccinelli P. Brucella abortus infection acquired in microbiology laboratories. J Clin Microbiol 2000;38:2005-6.

33. Sophie R, Michael L, Marcel B, Earl R. Prevention of laboratory-acquired brucellosis. Clin Infect Dis 2004;38:e119-22.

\section{Funding: None; Conflicts of Interest: None Stated.}

How to cite this article: Jabalameli M, Bagherifard A, Ghaderi MT, Motaghi P, Aghdam HA. Periprosthetic joint infection due to Brucella infection: A report of a rare presentation and review of the literature. Indian J Case Reports. 2021;7(4):158-164. 